\title{
TQM Implementation in Textile Manufacturing Industry to Success: Review and Case Study
}

\author{
Salman Khalid (Corresponding Author) \\ School of Management Studies \\ The University of Faisalabad, Faisalabad-37610, Pakistan
}

Tel: 92-300-865-3949_E-mail: salmankhalid77@yahoo.com

\author{
Muhammad Zohaib Irshad \\ Department of Business Administration \\ The Government College University Faisalabad, Faisalabad, Pakistan
}

Babak Mahmood

Assistant Professor, Department of Sociology

University of Sargodha, Sargodha, Pakistan

Received: July 2, 2011

Accepted: July 16, 2011

doi:10.5539/ibr.v4n4p242

\begin{abstract}
This exploratory study has provided an insight into implementation of TQM in Pakistani textile manufacturing industry and factors that were considered to be critical to adoption of TQM. The cross sectional results show that TQM is largely implemented in manufacturing/operating function and little in other functional areas. TQM is a philosophy mainly adopted by large organizations. Whereas, SME businesses are still lagging behind larger one's when it comes to introducing and adopting new managerial philosophy and advanced technology. Many SMEs have stopped at quality system certification, rather than pursing further continuous improvement efforts by adopting TQM. SMEs must understand the need to go beyond the quality system stage and work towards TQM for quality.
\end{abstract}

Keywords: TQM, Manufacturing, Implementation, Small and Medium enterprises (SME)

\section{Introduction}

Total quality management (TQM) has been a popular business strategy in many leading manufacturing organizations over the past few years (Sohal \& Terzivski, 2000). There are some manufacturing firms that have been successes, and some have been failed with TQM implementation. A large number of companies that have implemented TQM are large multinationals companies (MNCs) such as Hawlett-Packard (HP), International Business Machines (IBM), and Nokia. The practical use of quality methods in SME's are today still limited (Garvare \& Wiklund, 1997). The reasons are several but especially local networking between SME's and long term training in quality methods have been identified as critical factors for successful implementation (Sandvik, 1997).

In this era of global competition a company needs to apply new quality techniques in form of strategic management, quality assurance, quality systems, quality control etc. In other words organization has to implement the concept of TQM. This concept provides the approach to realize the manufacturing strategy leading to fulfillment of organization's corporate strategy (Sharma \& Kodali, 2008). The principles of TQM philosophy would increase a firm's commitment to quality and once they are applied correctly enhances the firm's competitiveness position in market, because the TQM principles support the business practices e.g. cost reduction, enhanced productivity, improved product quality and output.

The majority of successful manufacturing companies have adopted TQM techniques and acknowledged its intangible contribution. However, the importance of TQM practices as an effective pillar of corporate strategy for achieving manufacturing excellence cannot be denied. The concept of manufacturing excellence is regarded as the path to become the best manufacturer. Many researchers, while developing their frameworks have considered TQM as key element for achieving manufacturing excellence (Yusof \& Aspinwall, 2000).

The purpose of this study is to look at the various TQM implementation issues particularly in SMEs. The background section reviews the concept of SME and TQM in detail and some quality initiatives undertaken by SMEs. A wide range of literature is available on quality assurance and implementation of BS EN ISO 9000, while few studies focused on the application of the concept of total quality (Yusof \& Aspinwall, 2000). A short description 
of SME is also given to understand their problems. The case study part of paper presents a detail investigation report of a study conducted on Ihsan Yousaf Textile (PVT) Ltd. Faisalabad, Pakistan, involved in manufacturing. Various issues were investigated with respect to effective implementation of management practices, process, result and outcomes of such practices. The final section present the conclusion based on both reviews and case study facts.

\section{Background}

\section{The definition of SMEs}

Definition of Pakistani SME is based on the number of employees, total asset costs, and sales turnover. The Criterion used is almost similar to the other countries such as U.S.A., Japan, U.K., Korea and China. The State Bank of Pakistan defines SME "as an entity, manufacturing concern have full-time number of employees up to 250, total asset cost Rs. 100 Million, and total sales turnover not exceeding Rs. 300 Million per annum" (SBP, 2009). Studies show that only approximately 60 percent of SMEs survive for 3 years (Thomas \& Cornforth, 1989); and rest of 40 percent survive for 10 years (Philips \& Kirchhoff, 1989).

There are approximately 2 million SMEs in Pakistan (Hassan, 2008). These include 1,000,000 Trade sector units (retailers), 600,000 Service sector units, and 400,000 manufacturing units. SMEs constitute nearly 90 percent of all the enterprises in Pakistan, employees 80 percent of the non-agriculture labor force, and approximately 40 percent share in annual GDP (SMEDA, 2011).

\section{Characteristics of SME's}

According to MacGregor (2004) SME's characteristics are unique and different from large organizations, for example policy making, business structure, utilization of resources and procedures. SME organizations have flat structure with few management levels, flexible and informal dynamic strategies (McAdam, 2000), and have, according to Bryttling (1991), also less stability and market overview. In terms of culture they have shared unified culture with high degree of personal authority among staff and management due to lack of formality exists by the company size (Jenning \& Beaver, 1997). Generally, senior managers are fully involved in daily operations due to the size of the company, SMEs are recognized as having shortage of skills among working staff, and has been argued a deficit in management expertise (Huang \& Brown, 1999).

However, among other factors related to ownership and strategy, motivation and education of the employees are important elements which have appeared to be significant with success and growth of SME's (Storey, 1994). Further, Atkinson and Storey (1994), demonstrates that the probability of SME's undertaking training for their workforce appears to increase with size of the enterprises. Particularly external training focuses on deepening the skill base, whereas, according to Wiklund (1999), small firms require greater flexibility from their labor rather than deeper specific skills. Growing and successful SME's seem to behave differently Wiklund (1999). These SME's seem to be more likely to perceive the skill base of their company to be one of its comparative advantages and so might be expected actively to encourage workforce training to greater extent than other firms (Storey, 1994).

\section{The definition of TQM}

Different authors have given various definitions of Total Quality Management (TQM). Oakland (2003) defined it as an approach involving whole organization for understanding each activity of each individual at each management layer. This argument is supported by Escrig (2004) who considers TQM as a strategic action that focuses on managing the total organization to provide products or services that satisfy their customer needs by utilizing all resources. However, Yang (2006) defined TQM as an integrated management philosophy that includes several factors such as continuous improvement, processes, customer satisfaction, employee's participation, benchmarking, and suppliers.

Berry (1991) defined the TQM process as a total corporate focus on meeting customer's needs and significantly reducing costs resulting from poor quality by implementing new management system and corporate culture. The fundamentals of TQM have been described by many authors and encompass elements such as management commitment, employee's involvement, supplier partnership, continuous improvement etc. TQM is a way of managing an enterprise towards achieving business excellence (Dahlgaard et al., 1998). In short, TQM is the management of quality, in way that members satisfy internal and external customer needs by using strategic planning including all functional areas to achieve strategic goals.

\section{Implementation of TQM in the SME business}

Many of the studies that have examined the relationship between TQM and organizational performance, have focused on large organization (Watson, 2003), and literature recognizes that TQM studies on small and medium enterprises (SMEs) is limited (Walley, 2000).Early studies on total quality initiative in SMEs have largely focused on achieving product quality and application of statistical techniques. Moreno-Luzon (1993) reported that small firms lagging behind large firms in the application of TQM. However, successful small firms place more emphasis 
on product and process innovation, investing more in new producing technology, and have highly motivated management team with better managerial aptitude. They tended to have less qualified personnel than larger firms, through TQM, SMEs able to invest in training of their staff which leads to the track of improvement.

Goh and Ridgway (1994) found that most of companies, which they studied, firms viewed certification ISO 9000 to be the end point in their quality journey. Similar findings were also reported by Meegan and Toylor (1997); they also advocated the need for a cost-effective framework to implement TQM in SME business. Zetiel et al., (1994) found on a case study of small firms experienced in implementing TQM. That firm used an improvement approach that was very similar to the concept of quality circles and gave examples of projects. Not surprisingly, all these took place after ISO 9000 certification.

\section{Methodology}

In an attempt to understand that reality of small and medium enterprises (SMEs) quality initiatives, a case study in one (SME) business was conducted through a structured interview approach. A questionnaire was developed to obtain maximum information and perceptions with regard to management's practices on TQM, the implementation of numerous quality initiatives, how the process of implementation was conducted, the benefits of TQM and problems company faced as well as the factors that contribute to the success of TQM. Besides interviews, observations were made from the documents supplied by company, and three short visits at the plant were made.

\section{Background of the case study- IYT}

The company studied was Ihsan Yousaf Textile (PVT) Ltd, located in Faisalabad, Pakistan. It is one of the leading manufacturers of textile finished goods. Of the 225 employees working in company, 18 are of staff/management level. Only 10 people are employed in quality department which is about $4 \%$ of the total workforce and considered very lean. The IYT's organizational structure is still very much triangular in shape, where chairman heads the company, assisted by General Manager. The second layer of structure comprises of departmental manager including Grey Fabric Department, CAD CAM Studio (Designing Studio), Laser Engraving/ Exposing, Bleaching Plant, Printing, Quality Control department, Finishing, Panel Printing, Jigger Dyeing, Continues Thermo-sole Dyeing, Calendaring, Raising Machines, Rolling Department, Stitching Department, Research \& Development Department.

A series of awards, recognition and certifications are testimonies of this company's effort towards becoming a TQ company. They gained BS EN ISO 9001 certification in 1996, and received the certificate of "Confidence In Textiles" Tested for harmful substances according to Oeko-Tex® Standard 100- Germany.

\section{IYT's perception and practices towards TQM}

Top management of IYT believes in customer satisfaction through a continuous improvement culture. This intention has been translated into good management practices such as improving communication, taking care of employees and customers, team working, having clear vision and mission statement regarding the business; act as a key driver in continuous improvement. Continues improvement has been made possible through the commitment of top management. In terms of quality improvement both within functions and cross function teams exists. Several measures have been taken to ensure their customer satisfaction. The company has a customer relation manager who gathers information from customers and acts as central contact person. The company has conducted customer surveys, and has a formal customer complaints process to take immediate actions against customer queries.

Numerous measures are collected for quality performance and improvement such as scrap percentage, number of rejection or misprinting per day. Different types of quality tools and techniques are utilized for different processes. Having good management practices that promote human resource development (HRD) differentiates between a TQM and non-TQM company. Numerous practices to promote job satisfaction and continuous improvement have been practiced in the company. They include a system for job advancement, a reward system, provide education and training for employees; both skills and quality related. Some of the communication methods were established since implementation of TQM such as open door and monthly meetings. Also off site meetings were conducted by managers to discuss strategic issues.

\section{IYT's quality initiatives}

With regard to specific quality initiatives implemented to date by IYT, the quality manager indicated all the items listed in the questionnaire. Some of these were developing a mission statement, forming a quality committee, and ISO 9002 requirements. Other quality initiatives include advanced quality planning tools like supplier partnership, benchmarking, self assessment and a quality cost system. One of the questions regarding employee's education on TQ concept was not answered. However, during interviews with manager of quality and other departments, they had good understanding of TQ concept. There are still many employees who have not been trained in TQ but are 
involved in the implementing activities, because there are quality checks at every stage of manufacturing from grey bleaching to packing of finished goods.

\section{TQM process implementation -IYT}

The main reason for adopting a TQ strategy in this company was that top management had realized that it was necessary for business survival, and demand of their customers. The quality department manager also indicated that another motivating factor was the positive results that were achieved from continuous improvement such as scrape percentage, and customers demand. Since IYT work with large businesses globally which want their suppliers to continuously improve quality, IYT fully understand that only continuous improvement will result in a higher quality of products and services, improved employees satisfaction which result in satisfying their customers.

The steps taken to implement TQM and continuous improvement were training and education of staff, team development, quality committee to assure the quality and developing business management systems. In addition the company has an annual plan which sets out the agenda for improvement to achieve in upcoming year. Some of the achievements to date have been in area of workplace layout, and waste reduction up to 12 percent. The quality department manager was satisfied with the team based improvement activities which have contributed towards high quality and productivity in his production department.

\section{Outcomes from TQM practices - at IYT}

This study also investigated the results and outcomes from implementing TQM within IYT. The types of positive intangible outcomes ranged from employees who realized the importance of quality improvement, to feel pride in work, quality improvement became the part of their organizational culture and improved communication. In addition they mentioned improved teamwork, they feel that everyone was important, and everyone was acknowledged for his contribution. During the second visit to plant, a quality inspector was asked how he liked working in IYT, and he immediately replied that he was proud to be part of this company. In response to whether a quality culture should be developed prior to TQM implementation or develop as TQM progresses, the quality department manager agreed with the authors that it was an outcome of the whole TQM process and not something to be changed. Through the development of proper system and measure that improve and promote quality as seen in the case of IYT, one would easily expect to see a productive change in the organizational culture.

However, the company has achieved tangible outcomes such as improved product or service quality, an increase in number of employees in improved activities, increased sales, and improved both customer and employees satisfaction.

\section{Problems and obstacles faced by IYT-TQM implementation}

IYT faced very few problems but those indicated by them are crucial in the context of SME. Their main problems and obstacles were:

- Lack of human resources: This company's quality department with 10 employees has the overall responsibility for quality assurance, product testing, ISO 9001 and "Confidence In Textiles" Tested for harmful substances according to Oeko-Tex ${ }^{\circledR}$ Standard 100- Germany. Compliance and dealing with customer's feedback etc.

- Lack of involvement form non-production functions: Since company's core business is textile manufacturing, majority of improvement would come from manufacturing areas. Non-production areas such as marketing, purchasing, accounts and maintenance, comprised of small percentage of total employees and do not justify being involved in quality improvement activities. A company must understand that everyone in organization have to contribute directly or indirectly to achieve the quality of its product or service.

- Achieve too much in a short time: A company like IYT which is not always entirely satisfied with their current situation will continually try to find and adopt new ways to enhance their business. This can be perceived to be trying to do much, but in reality it may be gradual continuous improvement process. During this endless journey of quality, firm have to learn many things especially when little has actually been done in past. Time is needed in order to integrate the appropriate quality principles and techniques into the culture of the organization (Goetsch \& Davis, 1994).

\section{Success factors related to IYT}

The success factors particularly related to company were:

- systematic approach

- selective training

- establishing a good communication system

- having a continuous improvement system

- human resource development

- teamwork development, and

- effective and simple implementation framework 
The quality department manager laid emphasis during interview on the process of TQM adoption being all about continuous improvement and teamwork. The tools and techniques are just means to achieve the goals of continuous improvement. Developing employees' skills and capabilities through education and training is important so that company can continuously upgrade in terms of knowledge and skills for improvement. It is believed that these success factors are relevant with the context of a SME business and further studies would be needed to verify this and investigate their suitability to other SME businesses.

\section{Conclusion}

The argument that have been presented by different authors showed that there are strengths and weakness associated with adoption of TQM in SME businesses, and there are also some problems in implementation with the SME manufacturing sector. Success stories of TQM in literature may not reflect the actual realities faced by SME businesses in adopting quality initiatives. The review and the case study revealed there are two major problems generally faced by most SME's businesses on track of TQM. The first is financial and the second is general resource constraints such as time, manpower, technical and managerial expertise. Obviously, the owner of SME cannot afford this approach due to its adverse affect on their resource availability.

SME businesses must be presented with TQM approach which is attractive to them in as sense it must not promise to improve or change the everything, or to solve every problem but help them to be better in short span of time with long term sustainability.

\section{Future research}

A further case-based exploration approach should be carried out to better understand the applicability of TQM in SME. Another area that requires further exploration includes the investigation of management's role in supplier's selection and evaluation in TQM. Also, the use of information systems (IS) and technologies to support TQM is an emerging area for further research. Finally, it is necessary to investigate the behavioral and cultural issues that can influence the applicability of TQM.

\section{References}

Atkinson, J., \& Storey, D. (1994). Employment, the Small Firm and Labor Market. London: Routledge.

Berry, T.H. (1991). Managing the Total Quality Transformation. New York: McGraw-Hill.

Bryttling, T. (1991). Organizing in Small Growing Firm: A Grounded theory Approach. Stockholm Economic Research institution: Stockholm School of Economic.

Dahlgaard, J.J., Kristensen, K., \& Kanji, G.K. (1998). Fundamentals of Total Quality Management. London: Chapman and Hall.

Escrig, A.B. (2004). TQM as a competitive factor: a theoretical and empirical analysis. International Journal of Quality \& Reliability Management, 21(6), 612-637. doi:10.1108/02656710410542034, http://dx.doi.org/10.1108/02656710410542034

Garvare, R., \& Wiklund, H. (1997). Facilitating the use of Statistical Methods in Small and Medium size enterprises. Processeding of EOQ-97, Vol. 3.

Goetsch, D., \& Davis, S. (1994). Introduction to quality: Quality, Productivity, Competitiveness (2nd ed.). London: Macmillan.

Goh, P.L., \& Ridway, K. (1994). The implementation of total quality management in small- and medium sized manufacturing companies. TQM Magazine, 6(2), 54-60. doi:10.1108/09544789410054064, http://dx.doi.org/10.1108/09544789410054064

Hassan, U.M. (2008). Microfinance in Small and Medium-sized Enterprises (SMEs) in Pakistan: Practices and problems in the prevailing system and prospects for Islamic finance. Kyoto Bulletin of Islamic Area Studies, 2(1), 231-237.

Huang, X., \& Brown, A. (1999). An analysis and classification of problems in small business. International Small Business Journal, 18(1), 73-85. doi:10.1177/0266242699181004, http://dx.doi.org/10.1177/0266242699181004

Jennings, P., \& Beaver, G. (1997). The performance and competitive advantage of small firms: a management perspective. International Small Business Journal, 15(2), 63-75. doi:10.1177/0266242697152004, http://dx.doi.org/10.1177/0266242697152004

MacGregor, R.C. (2004). Factors associated with formal networking in regional small business: some findings from a study of Swedish SMEs. Journal of Small Business and Enterprise Development, 11(1), 60-74. doi:10.1108/14626000410519100, http://dx.doi.org/10.1108/14626000410519100

McAdam, R. (2000). The implementation of re-engineering in SMEs: a grounded study. International Small Business Journal, 18 (4), 29-45. doi:10.1177/0266242600184002, http://dx.doi.org/10.1177/0266242600184002 
Meegan, S.T., \& Taylor, W.A. (1997). Factors influencing a successful transition from ISO 9000 to TQM. International Journal of Quality and Reliability Management, 14(2), 100-117. doi:10.1108/02656719710165383, http://dx.doi.org/10.1108/02656719710165383

Moreno-Luzon, M.D. (1993). Can total quality management make small firms competitive? Total quality Management, 4(2), 165-181. doi:10.1080/09544129300000027, http://dx.doi.org/10.1080/09544129300000027

Oakland, J. (2003). Total Quality Management: Text with cases. Oxford: Elsevier Butterworth Heinemann.

Phillips,B.D., \& Kirchhoff, B.A. (1989).Innovation and Growth Among New Firms in the US Economy. Wellesly, MA:Babson, Entrepreneurial Research Conference.

Sharma, M., \& Kodali, R. (2008). TQM implementation elements for manufacturing excellence. The TQM Magazine, 20(6), 599-621. doi:10.1108/17542730810909365, http://dx.doi.org/10.1108/17542730810909365

Small \& Medium Enterprises Development Authority. (2011). State of SMEs in Pakistan. Retrieved from Small \& Medium Enterprises Development Authority Web site: http://www.smeda.org.pk/main.php?id=34

Sohal, A.S., \& Terzivski, M. (2000). TQM in Australian manufacturing: factors critical to success. International Journal of Quality \& Reliability Management, 17 (2), 158-167. doi:10.1108/02656710010304564, http://dx.doi.org/10.1108/02656710010304564

State Bank of Pakistan. (2011). Prudential regulations for small and medium enterprises financing. Retrieved from State Bank of Pakistan Web site: http://www.sbp.org.pk/publications/prudential/PRs-SMEs.pdf

Storey, D., (1994). Understanding the Small Business Sector, London. : Routledge.

Thomas, A., \& Cornforth, C. (1989). The survival and growth of worker's co-operatives: A comparison with small businesses. International small business Journal, 8(1), 34-50. doi:10.1177/026624268900800103, http://dx.doi.org/10.1177/026624268900800103

Walley, K. (2000). TQM in Non-Manufacturing SMEs: Evidence from the UK Farming Sector. International Small Business Journal, 18(4), 46-61. doi:10.1177/0266242600184003, http://dx.doi.org/10.1177/0266242600184003

Watson, J. (2003). The impact of TQM adoption on SME financial performance. 16th Annual Conference of Small Enterprise Association of Australia and New Zealand, pp. 1-9.

Wiklund, H., (1999).A collaboration concept for TQM implementation in small and medium sized enterprises. Journal of Applied Quality Management, 2(1), 101-105. doi:10.1016/S1096-4738(99)80006-2, http://dx.doi.org/10.1016/S1096-4738(99)80006-2

Yang, C.C. (2006). The impact of human resources management practices on the implementation of total quality management. The TQM Magazine, 18(2), 162-173. doi:10.1108/09544780610647874, http://dx.doi.org/10.1108/09544780610647874

Yusof, S.M., \& Aspinwall, E.M. (2000). A conceptual framework for TQM implementation for SMEs. The TQM Magazine, 12(1), 31-6. doi:10.1108/09544780010287131, http://dx.doi.org/10.1108/09544780010287131

Zetie, S., Sparrow, J., Woodfield, A., \& Kilmartin, T. (1994). Hydrapower dynamics: service delivery improvement in a small organization, in Teare, R. et al., (Ed.), Achieving Quality Performance: Lessons from British Industry (pp.54-78). London: Cassell. 